
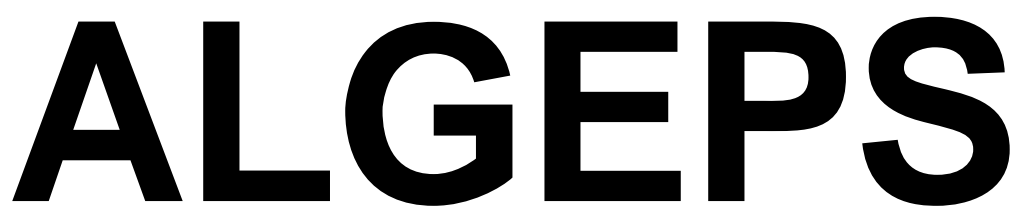

REVISTA DE GEOLOGIA, SĖRIE B no 644 - Agost del 2013

\begin{abstract}
MODIFICACIONS A L'ITINERARI GEOLÒGIC PER LES COMARQUES DEL BAIX LLOBREGAT I DEL VALLÈS OCCIDENTAL: DES D'OLESA DE MONTSERRAT A RIBES BLAVES, SANT PERE SACAMA, A L'ESTACIÓ D’OLESA, A LA CARENA LLARGA I A VACARISSES
\end{abstract}

Josep M. Mata-Perelló i Joaquim Sanz Balagué

Aquest recorregut va ésser experimentat amb docents el dia 21D DE GENER DEL 2012 


\section{MODIFICACIONS A L'ITINERARI GEOLÒGIC PER LES COMARQUES DEL BAIX LLOBREGAT I DEL VALLÈS OCCIDENTAL: DES D’OLESA DE MONTSERRAT A RIBES BLAVES, SANT PERE SACAMA, A L'ESTACIÓ D’OLESA, A LA CARENA LLARGA I A VACARISSES ${ }^{1}$}

Per Josep M. MATA-PERELLÓ

\section{ADVERTIMENT PREVI}

Com en altres recorreguts de RECERCA GEOLÒGICA I MINERALÒGICA ..., si es disposa del temps suficient, poden efectuar-se passant per totes les parades i filloles. En cas contrari, recomanem prescindir de les anomenades PARADES CONDICIONALS.

En aquesta ocasió, el recorregut s'efectuarà en algun tram, per camins no gaire bons. Caldrà buscar la informació suficient sobre el seu estat.

A l'igual que als altres itineraris realitzats fins ara, recomanem tenir la màxima cura de respecte cap al Medi Natural i cap al Medi Ambient al llarg de tot el recorregut, i també fora d'ell.

\section{BREU INTRODUCCIÓ}

En aquesta ocasió, el recorregut del present itinerari discorrerà en la seva major part pel Sistema Mediterrani (una de les tres unitats geològiques que constitueixen el nostre país), i més concretament per la seva sotsunitat més externa: la Serralada Prelitoral Catalana. Tot i així, el recorregut s'iniciarà dintre d'una altra sotsunitat, la Depressió Prelitoral Catalana (la qual pertany, també al Sistema Mediterrani, com la sotsunitat abans esmentada).

Per d'altra banda, en el transcurs del recorregut, també es recalarà sobre els trams més meridionals de la Depressió Central (la qual pertany a la Depressió Geològica de l'Ebre, una altra de les tres unitats geològiques que constitueixen Catalunya). Això succeirà a les darreres aturades del recorregut.

\footnotetext{
${ }^{1}$ MODIFICACIONS AL RECORREGUT DE L'ITINERARI GEOLÒGIC PER LES COMARQUES DEL BAIX LLOBREGAT I DEL VALLÈS OCCIDENTAL: DES D'OLESA DE MONTSERRAT A RIBES BLAVES, A L'ESTACIÓ D’OLESA, A TORREBLANCA I A VACARISSES / 21 DE GENER DEL 2012 (ALGEPS 641)
} 
També cal dir, que el recorregut de l'itinerari s'efectuarà per les comarques del Vallès Occidental i del Baix Llobregat, ambdues de la I ${ }^{a}$ Regió (o Regió de Barcelona). Així, s'iniciarà a la primera, per a finalitzar a la segona.

Així, s'iniciarà a la població d'Olesa de Montserrat i tot seguit el recorregut es desplaçarà cap als indrets de Ribes Blaves, Estació de la RENFE a Olesa, per a continuar després cap a Torreblanca i Vacarisses.

\section{OBJECTIUS FONAMENTALS D'AQUEST ITINERARI}

Els objectius fonamentals que es pretenen aconseguir en aquest itinerari, es poden concretar en els següents aspectes generals:

1.- Observació de l'estructura de la Depressió Prelitoral Catalana (del Sistema Mediterrani), per on s'efectuarà el primer tram del recorregut, entre Olesa de Montserrat i el paratge de Ribes Blaves.

2.- Observació dels materials miocènics que constitueixen la Depressió Prelitoral Catalana. A la primera aturada els veurem recoberts per sediments detrítics quaternaris. I a la segona els veurem en contacte amb els paleozoics per la Falla Nord del Vallès-Penedès.

3.- Observació de l'estructura de la Serralada Prelitoral Catalana, per la qual discorrerà bona part de recorregut del present itinerari, entre Ribes Blaves y el Pont del Mimó, anant cap a les immediacions de Torreblanca.

4.- Observació dels materials paleozoics (de 1'Ordovicià i del Silurià) i dels mesozoics (del Triàsic), els quals constitueixen la Serralada Prelitoral Catalana, pels indrets on discorrerà el recorregut de l'itinerari, entre els indrets abans esmentats.

5.- Observació de les relacions estructurals entre les dues unitats geològiques acabades d'esmentar: entre la Depressió Prelitoral Catalana i la Serralada Prelitoral Catalana. Tanmateix, observació de l'encavalcament de les Pedritxes per les immediacions de Vacarisses. I, també, si s'escau, a la darrera aturada entre aquesta serralada i la Depressió Geològica de l'Ebre.

6.- Observació al llarg del recorregut dels impactes creats per les obres públiques (com l'Autopista) i per les explotacions mineres (la pedrera de Coll Cardús). I en tot cas: observació de les restauracions dutes a terme, si es dona el cas.

7.- Observació, al llarg del recorregut dels indrets relacionats amb el Patrimoni Geològic. Així, cal fer esment de l'interessant paratge de Ribes Blaves.

\section{ANTECEDENTS BIBLIOGRÀFICS}


Pel que fa als antecedents relacionats amb altres itineraris geològics, que discorrin per aquesta zona, ens referirem als de: CALZADA i GAETANI (1977), CALZADA i JAIME (1978), MASACHS et altri (1981); i també a diferents treballs nostres: MATA-PERELLÓ (1984a, 1984b, 1995, 1996, 1999, 2001, 2006, 2007, 2009a 2009 b i $2012^{2}$ ). Fora d'aquests, no en coneixem cap altre.

Pel que fa amb els treballs relacionats amb els caràcters generals de la geologia de la zona, ens referirem als següents antecedents: GUIMERÀ et altri (1992), LLOPIS LLADÓ (1974), MARZO i ANADÓN (1977), RIBÁ (1976), SOLER (1982) i VIRGILI (1858). Pel que fa als minerals i als jaciments mineralògics, cal parlar d'un altre treball nostre: MATA-PERELLÓ (1991).

Tanmateix, cal fer esment del nostre treball: MATA-PERELLÓ i CLIMENT FERRAN (2010), dedicat íntegrament al coneixement de la geologia de la comarca del Baix Llobregat.

Més endavant, dintre de l'apartat dedicat a les REFERENCIES BIBLIOGRÀFIQUES ja ens referirem a tots ells.

\section{RECORREGUT DE L'ITINERARI}

El recorregut del present itinerari començarà dintre del Baix Llobregat, a la població d'Olesa de Montserrat, per on es realitzaran las primeres aturades d'aquest itinerari.

Després, el recorregut es dirigirà cap als paratges de Ribes Blaves (per on s'efectuarà una aturada). Tot seguit, el recorregut es dirigirà cap les immediacions de l'Estació de la RENFE d'Olesa de Montserrat (situada al terme de Viladecavalls del Vallès); tot i així es farà una fillola, per tal d'anar al pont de la carretera B - 120 sobre la Riera de Sant Jaume.

A l'esmentada Estació d'Olesa de Montserrat, on es farà una doble aturada, una a la mateixa estació i una altra per sota d’ella, a la carretera que duu cap a Vacarisses.

Tot seguit, s’anirà (per la carretera) cap al Pont del Mimó, per on es farà una nova aturada. Després, el recorregut continuarà cap a la població de Vacarisses, per on es faran les darreres aturades, finalitzant el recorregut de l'itinerari.

\section{DESCRIPCIÓ DE L'ITINERARI}

\footnotetext{
${ }^{2}$ EL PRESENT ITINERARI SUPOSA UNES LLEUGERES MDIFICACIONS I AMPLIACIONS AL RECORREGUT DE L'ITINERARI GEOLÒGIC PER LES COMARQUES DEL BAIX LLOBREGAT I DEL VALLÈS OCCIDENTAL: DES D'OLESA DE MONTSERRAT A RIBES BLAVES, A L'ESTACIÓ D’OLESA, A TORREBLANCA I A VACARISSES / 21 DE GENER DEL 2012
} 
Com de costum, estructurarem el recorregut de l'itinerari en una sèrie de PARADES, que tot seguit anirem veient. En cadascuna d'aquestes aturades farem un breu comentari (geològic o mineralògic, segons s'escaigui).

En cada cas indicarem, entre parèntesi el full topogràfic del "Mapa Topogràfico Nacional" a escala 1:50.000, de 1'Instituto Geográfico Nacional, on es troba l'aturada, que en aquest cas seran sempre els fulls 391 (o d’Igualada) i 392 (dit de Sabadell).

Així doncs, la relació ordenada de les parades que composen aquest itinerari, és la següent:

PARADA 1 CONDICIONAL. SORTIDA D'OLESA DE MONTSERRAT CAP A TERRASSA (terme municipal d'Olesa de Montserrat, comarca del Baix Llobregat ). (Full 392).

El recorregut de l'itinerari començarà a la població d'Olesa de Montserrat, al bell mig de la ciutat.

Aquesta població es troba dintre de la Depressió Prelitoral Catalana, entre afloraments dels materials cenozoics del Miocè que la reblen. Tot i així, aquests materials no es fan palesos, ja que es troben recoberts per sediments terrígens del Quaternari.

\section{PARADA 2. PARATGE DE RIBES BLAVES, (terme municipal d'Olesa de Montserrat, comarca del Baix Llobregat). (Full 392).}

Després de fer l'aturada anterior, cal sortir d'Olesa de Montserrat, per la carretera que es dirigeix cap a Terrassa (la B-120). En arribar a 1'indret de Ribes Blaves, farem una nova aturada, després de recórrer uns $4 \mathrm{Km}$ de la parada anterior

En aquest recorregut, en un principi hem anat trobant els materials esmentats a la parada anterior, els quals sovint s'han trobat recoberts per terrenys detrítics quaternaris. Tot i així, prop de l'indret de l'aturada s'han anat trobant afloraments dels materials paleozoics de 1'Ordovicià. Aquests materials paleozoics estan constituïts per fil·lites vinoses, metapsamites o gresos metamorfitzats, i esquists grisos i negres.

Uns i altres estan, sovint, travessats per filons de quars. 'indret de Ribes Blaves, està situat sobre la falla que posa en contacte els materials paleozoics amb els miocènics que constitueixen la Depressió del Vallès (nom local de la Depressió Prelitoral Catalana). Aquest nom ("Ribes Blaves"), ve del color que prenen els materials de la bretxa de falla, procedents de la trituració d'esquists i psammites.

La falla en qüestió, té una direcció E-W, constitueix el contacte entre la Serralada Prelitoral i la Depressió abans esmentada, essent el seu salt de més de 2000 m (d'acord amb els sondejos fets al Vallès). 
La bretxa de falla té una amplada de quasi 100 m, i està formada per materials paleozoics trinxats i triturats, entre els quals es troben alguns tascons, formats per esquists, sense triturar.

Per d'altra banda, es molt interessant veure la típica morfologia de "Bad-lands", (o Xaragalls) desenvolupada entre els materials que formen la bretxa de falla. Sense cap mena de dubte, aquest indret constitueix un immillorable exemple de l'esmentada morfologia. Sobre els materials paleozoics trinxats, s'han originat profundes torrentades, que es dirigeixen majoritàriament cap a la Riera de Sant Jaume. Relacionats amb els xaragalls, és freqüent trobar bons exemples d'estructures piramidals.

Aquest indret forma part del Patrimoni Geològic de la Comarca del Baix Llobregat i tanmateix del conjunt de Catalunya. Per d'altra part, forma part de l'Inventari del Patrimoni Geominer que en aquests moments s'està confeccionant per part del Centre d'Estudis de la Comarca del Baix Llobregat.

També és interessant observar la forta erosió remuntant de la Riera de Sant Jaume, en direcció W, que a la llarga pot arribar a la captura del Torrent de Coll Blanc, que fa el desguàs de Ribes Blaves per la seva part occidental. L'esquema és el següent (ESQUEMA 1 i FOTOGRAFIA 1):

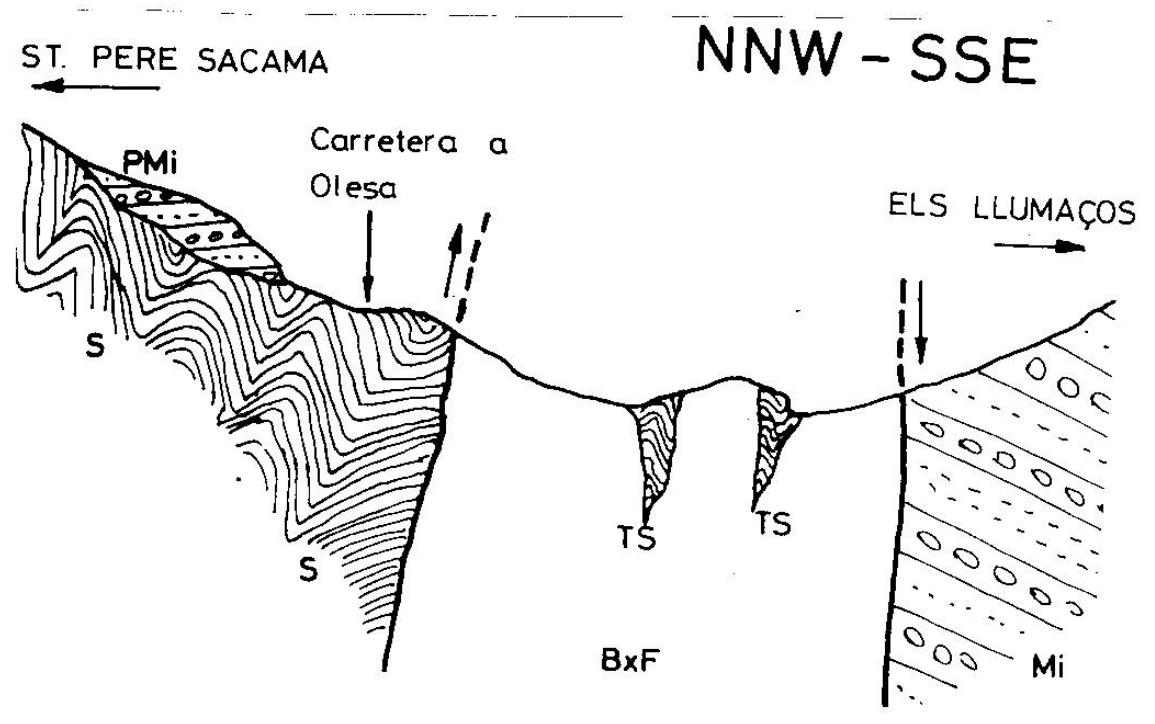

S. Silurià (esquists, psammites)

Mi. Miocè (gresos i conglomerats)

Pmi. Materials post-miocènics (gresos amb llits de conglomerats)

BxF. Bretxa de Falla

Ts. Tascons de Silurià

ESQUEMA 1

Tall reproduït de MATA-PERELLÓ (1984a) 


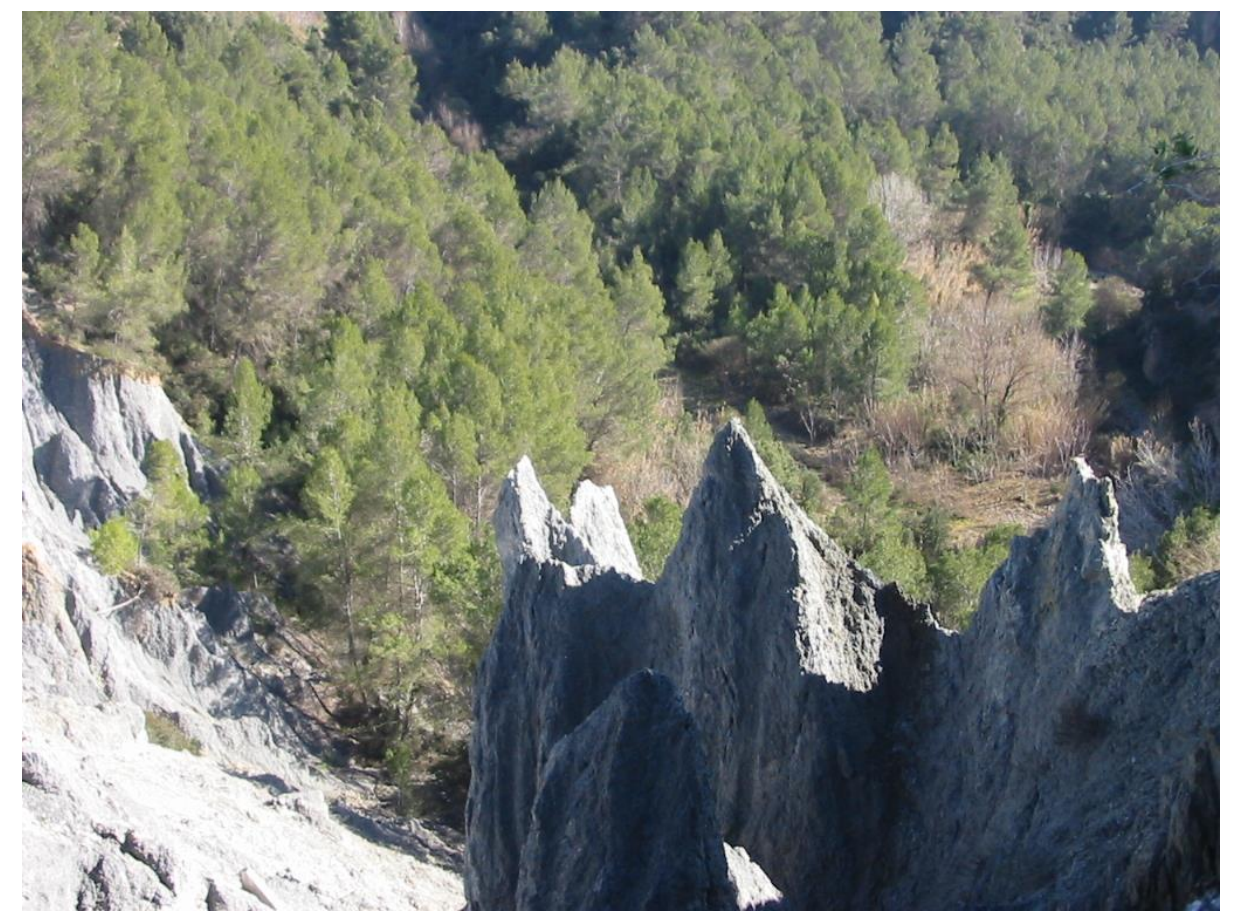

FOTOGRAFIA 1

Aspecte dels xaragalls (bad-lands) desenvolupats a Ribes Blaves, sobre la milonita de la falla

PARADA 3. PUJADA CAP A SANT PERE SACAMA, (terme municipal d'Olesa de Montserrat, comarca del Baix Llobregat). (Full 392).

Després de fer l'aturada anterior, cal tornar a la carretera B- 120 la qual es dirigeix cap a Terrassa). A uns 150 metres més enllà, cal agafar un camí en no gaire bon estat, que ascendeix cap a Sant Pere Sacama. A uns 0'9 Km i escaig, cal fer una nova aturada, a poc més de $2 \mathrm{Km}$ de la darrera aturada.

En aquest recorregut, fins arribar a la cruilla, s'han anat tallant els materials paleozoics, els quals es troben constituïts per nivells d'esquistos i de llicorelles, molt sovint recoberts per terrenys quaternaris. Així, tot aquest recorregut, fins a l'indret de l'aturada, s'haurà efectuat entre els materials paleozoics de la Serralada Prelitoral Catalana, constituïts per nivells de pissarres que pertanyen primer al Silurià, i després a l’Ordovicià.

Aquests materials es troben sovint travessats per petits filonets de quars, i també per falles. Per d'altra banda, es poden trobar bons exemples de plecs en knick i plecs en chevron, com els que es poden veure a uns $300 \mathrm{~m}$ de l'inici d'aquest camí. FOTOGRAFIA 2. 


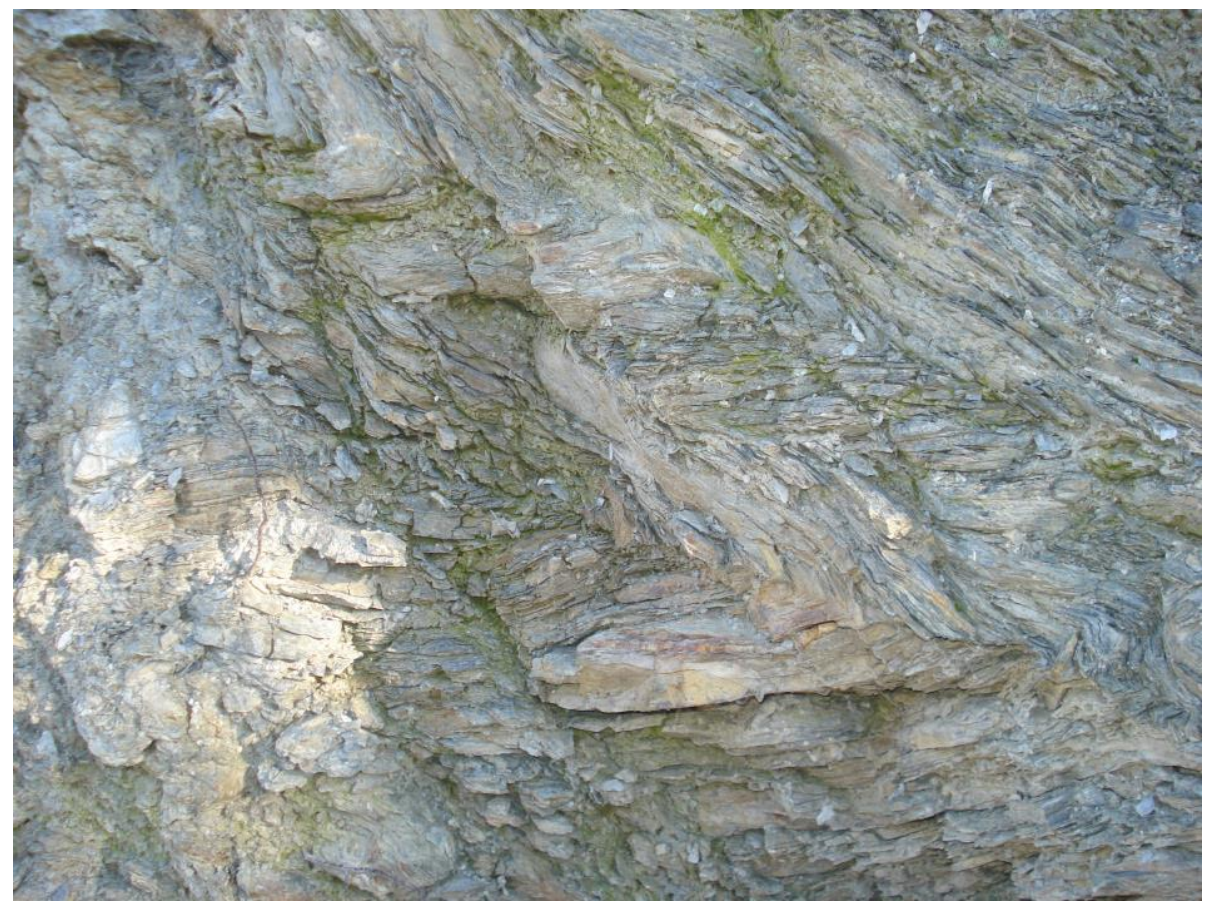

FOTOGRAFIA 2

Aspecte de les fracturacions i dels plecs entre els materials de 1’Ordovicià

\section{PARADA 4. LA TEULERIA DE SANT PERE SACAMA, (terme municipal d'Olesa de Montserrat, comarca del Baix Llobregat). (Full 392).}

Des de la parada anterior, cal continuar per la carretera que es dirigeix cap a Terrassa. A uns 0'2 Km es trobarà un trencall, per l'esquerra, que ens caldrà agafar, per tal de continuar per aquest camí-carreter, que en uns $2 \mathrm{Km}$ arriba fins a l'ermita romànica de Sant Pere Sacama. A uns $300 \mathrm{~m}$ abans d'arribar-hi, farem una nova aturada en una antiga teuleria, recentment restaurada. Així, des de la parada anterior, haurem recorregut gairebé uns 1`5 Km.

Al llarg d'aquest recorregut, des de la parada anterior, tot mirant cap al Sud i cap al $\mathrm{SE}$, es poden veure les diferents unitats geològiques que configuren els Catalànids (o Sistema Mediterrani). Així, en primer terme es pot veure la Serralada Prelitoral Catalana (on ara estem situats). Més enllà es pot veure la Depressió Prelitoral Catalana (on es situen les properes poblacions d'Olesa, Abrera i Esparreguera). Més enllà es pot veure la Serralada Litoral Catalana (amb els relleus del Bloc de Garrafi de Collserola). I fins i tot, més enllà es pot veure la Depressió Litoral Catalana (amb el delta del Llobregat). I més enllà el mateix mar.

Per d'altra banda, en tot aquest recorregut, hem continuat trobant afloraments dels materials paleozoics, representats sovint per llicorelles. Per sobre d'aquests materials hem anat trobant afloraments dels derrubis de pendent quaternaris. formats per fragments de pissarres, sovint alterades i meteoritzades a argiles. Precisament, en aquest indret han estat utilitzats aquests materials per a la fabricació de teules. Així, ara veiem una vella teuleria, recentment restaurada. (FOTOGRAFIES 3 i 4). 


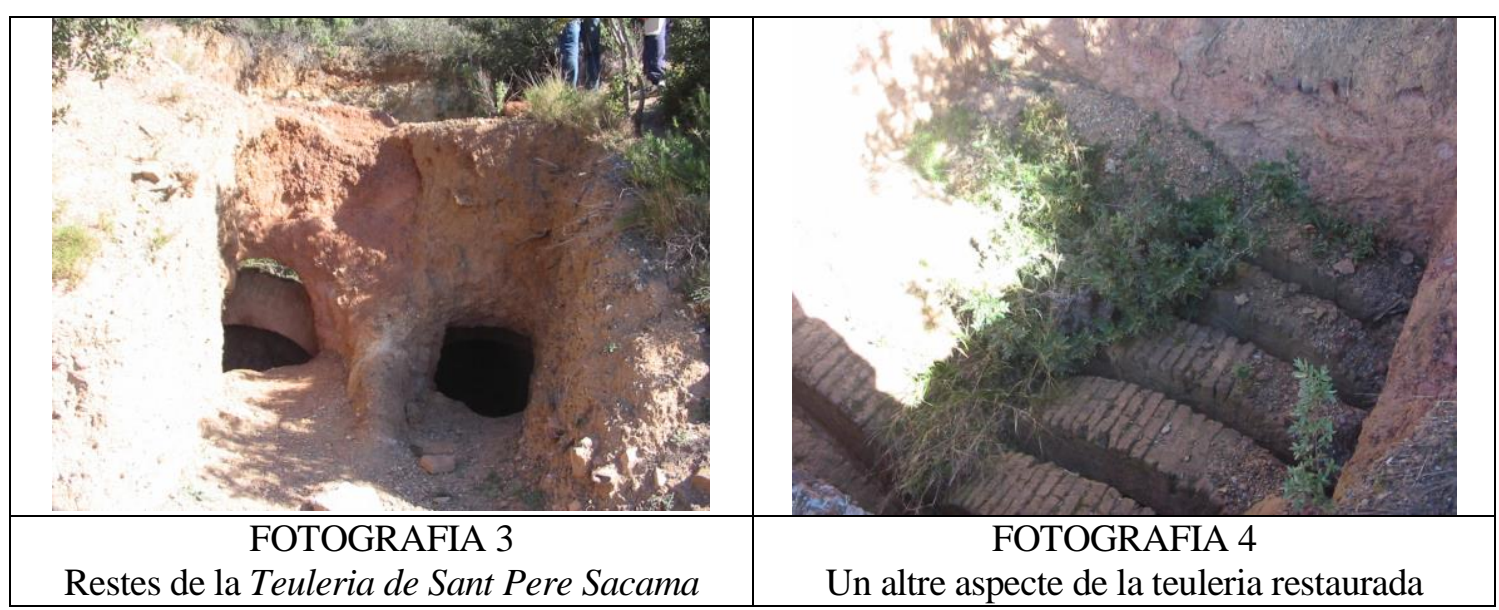

Cal dir que aquesta teuleria es un element molt important del nostre Patrimoni Miner, que cal conservar.

\section{PARADA 5. ERMITA DE SANT PERE SACAMA, (terme municipal d'Olesa de Montserrat, comarca del Baix Llobregat). (Full 392).}

Des de la parada anterior, cal continuar pel camí que es dirigeix cap a l'ermita romànica de Sant Pere Sacama. A uns 300 metres, després d'haver fet l'altra parada hi arribarem. Aquí, farem una nova aturada.

En aquest recorregut, fins arribar-hi, haurem anat trobant els materials esmentats al trajecte anterior: els materials paleozoics constituïts per nivells d'esquistos i de llicorelles. Així, tot aquest recorregut, s'haurà efectuat de nou entre els materials paleozoics de la Serralada Prelitoral Catalana. Aquests materials es troben sovint travessats per petits filonets de quars, i també per falles.

A l'ermita de Sant Pere Sacama, es troba el contacte discordant entre els materials paleozoics anteriorment esmentats (els quals pertanyen molt probablement a 1'Ordovicià i al Silurià) i els nivells inferiors mesozoics (els quals pertanyen al Triàsic Inferior; és a dir al Buntsandsteim). En aquest indret, els conglomerats basalts del Buntsandsteim apareixen en situació vertical. Donada la seva resistència a l'erosió destaquen sobre els materials circumdants, produint la formació d'hokbacks o d'espases. Precisament, sobre una d'aquestes espases es on es troba situada i enlairada l'ermita de Sant Pere Sacama, on ara ens trobem.

També cal dir que aquests conglomerats són de caràcter quasi exclusivament quarsífer, amb ciment i matriu silícica. Per d'altra banda, cal dir que sovint contenen petits creixements de BARITINA, situats entre el ciment silici.

Precisament, des del darrere de l'ermita, es possible veure els indrets de l'esmentada aturada. Tanmateix es pot veure l'aflorament gairebé continuat dels materials basals del Buntsandsteim, entre aquella parada i la present. L'esquema d'aquests contacte, és el següent (ESQUEMA 2 i FOTOGRAFIA 5, pàgina següent) 

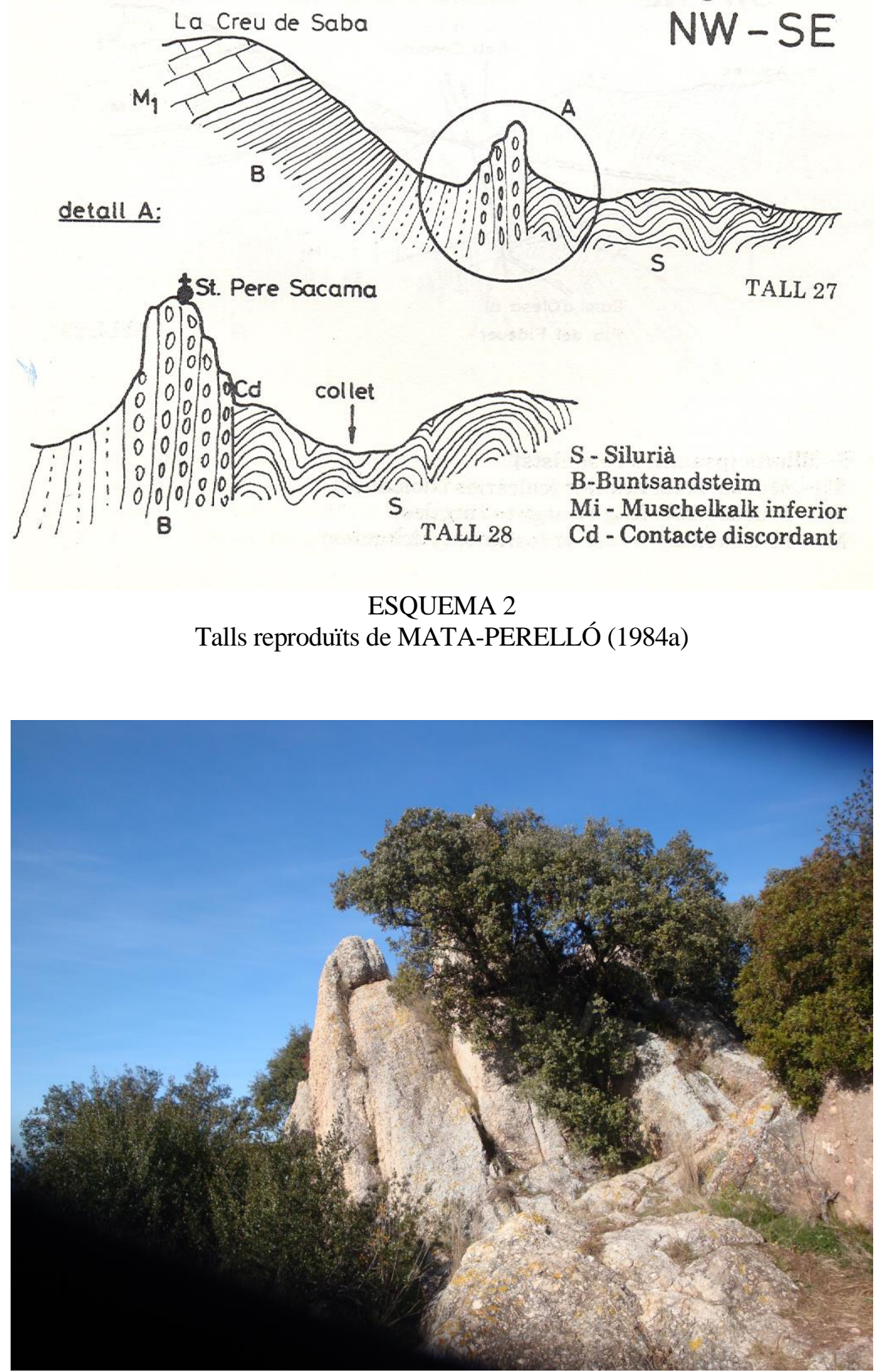

FOTOGRAFIA 5

Un altre aspecte dels conglomerats i bretxes basals del Buntsandsteim a Sant Pere Sacama

Per d'altra banda, des d'aquest indret, i en dies de bona visibilitat, es possible gaudir d'una bona observació dels diferents sectors que constitueixen el Sistema Mediterrani. Així, es pot veure la Serra de Collserola (de la Serralada Litoral Catalana), un ampli 
sector de la Depressió del Vallès (Depressió Prelitoral Catalana), i també molts sectors de la Serralada prelitoral Catalana, on ara ens trobem, con la Serra de Coll Cardús, o com les Preditxes.

També es pot observar un extens sector de la Serra de l'Ubac, així com de Sant Llorenç de Munt, que pertanyen a la Depressió Geològica de l'Ebre, i més concretament als denominats Altiplans Meridionals.

Per d'altra banda, mirant cap a 1'Est, es poden veure els reforçaments fets sobre l'autopista, per tal d'evitar les contínues esllavissades que s'havien anat produint durant els darrers anys, trobant-se ara aturades. FTOGRAFIA 6.

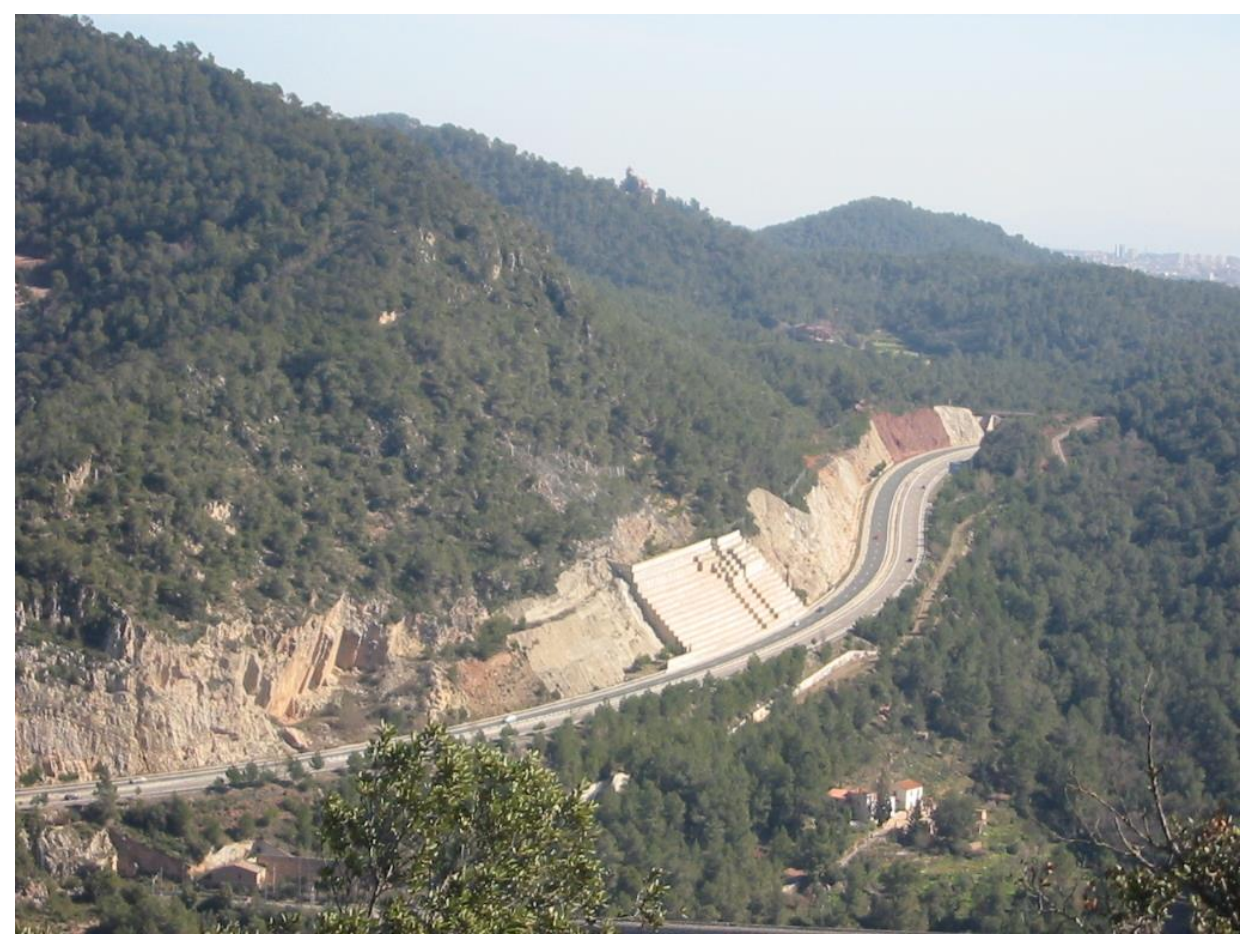

FOTOGRAFIA 6.

Les obres efectuades, per tal de fixar els despreniments a l’Autopista Terrassa - Manresa

PARADA 6. COLL VENTÓS, (terme municipal d’Olesa de Montserrat, comarca del Baix Llobregat). (Full 392).

Des de l'anterior parada, a Sant Pere Sacama, cal retrocedir pel camí que hem seguit des de la carretera, fins trobar un trencall per la dreta (després d'una baixada, en una corba). D'aquí surt un altre camí en no gaire bon estat. Aquest camí en uns $2 \mathrm{Km}$ ens acosta al Coll Ventós. Abans haurem trobat un altre camí que procedeix d'Olesa de Montserrat. Finalment, en arribar al Mas de Coll Ventós, farem una nova aturada, a uns $2 \mathrm{Km}$ de la parada anterior. Tot i així, abans d'arribar a l'indret de l'aturada, haurem trobat el corriolet que procedeix directament de Sant Pere Sacama, on hem fet la parada anterior. 
En aquest recorregut, haurem trobat afloraments dels materials paleozoics que hem vist a l'aturada anterior. Més endavant, poc abans de trobar el corriolet que ve de Sant Pere Sacama, haurem trobat afloraments dels materials rogencs del Buntsandsteim, amb nivells de gresos i calcolutites roges.

Després, per sobre del Coll Ventós comencen a aparèixer els nivells del Muschelkalk Inferior, constituïts per calcàries i dolomies, que pertanyen als seus estatges inferiors. Mes amunt d'aquests materials es poden veure uns trams rogencs (amb gresos, lutites i calcolutites) que pertanyen al Muschelkalk Mig. I, més amunt s'observen uns altres trams carbonatats (amb calcàries i dolomies), que pertanyen al Muschelkalk Superior.

Des del Coll Ventós és possible veure una falla, situada a l'altra vesant del Barranc de la Creu Beca, entre les Agulles i el Puig Cendrós. Es tracta d'una falla que posa en contacte els nivells calcaris del Muschelkalk amb els materials paleozoics del Silurià.

L'esquema d'aquesta falla és troba representat a l'ESQUEMA 3 i tanmateix a la FOTOGRAFIA 7, de la pàgina següent):

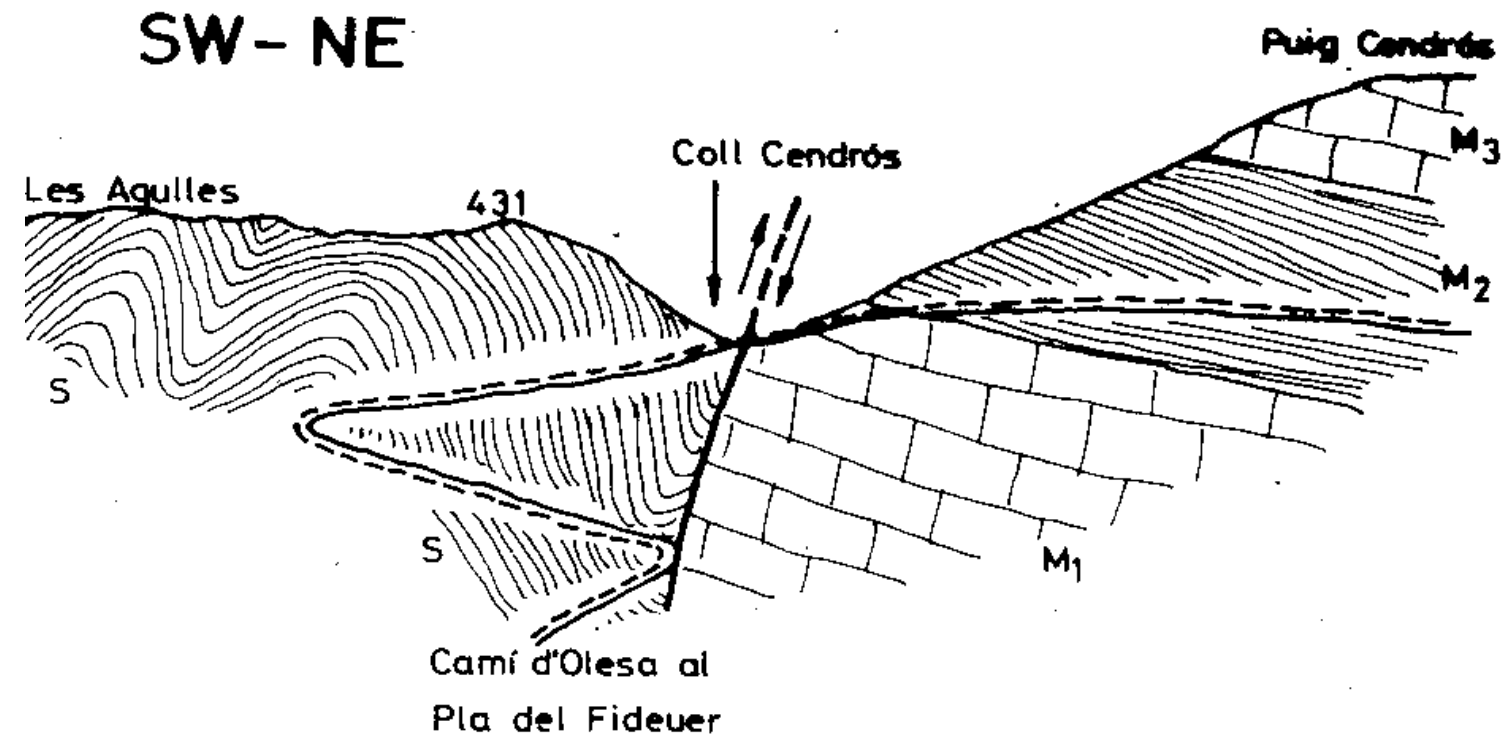

S. Silurià (psamites i esquists)

M1. Muschelkalk Inferior (calcaries i dolomies)

M2. Muschelkalk Mig (margues, gresos i argiles)

M3. Muschelkalk Superior (calcaries i dolomies)

ESQUEMA 3

Talls reproduïts de MATA-PERELLÓ (1984a) 


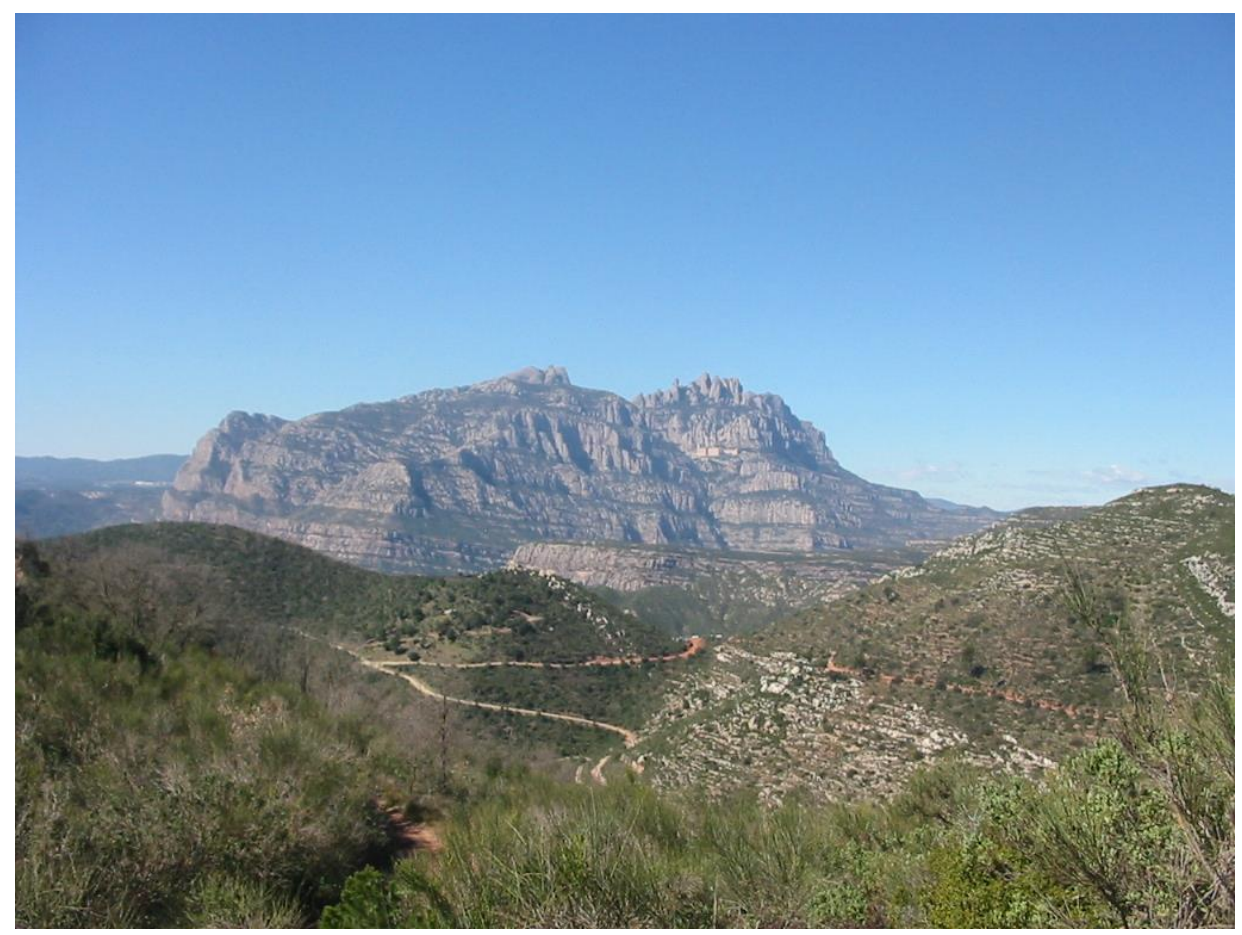

FOTOGRAFIA 7

Falla del Coll Ventós

\section{PARADA 7. PONT SOBRE EL TORRENT DE SANT JAUME, (termes municipals d'Olesa de Montserrat i de Viladecavalls del Vallès, comarques del Baix Llobregat i del Vallès Occidental). (Full 392).}

Des de la parada anterior cal tornar enrere, pel camí n gaire bo que hem seguit per arribar fins aquí. Inicialment ens cal arribar fins a la cruilla amb el que procedeix de Sant Pere Sacama. I tot seguit ens cal arribar de nou fins a la carretera B -120 (que hem agafat a Olesa de Montserrat i que es dirigeix cap a Terrassa i Vacarisses). Nosaltres, haurem de continuar per la que es dirigeix cap a Terrassa, tot fent una fillola, Amb la intenció d'arribar al pont sobre la Riera de Sant Jaume, per on cal fer una nova aturada, a uns 5’5 Km de 1'anterior i a uns $2 \mathrm{Km}$ de la cruïlla. Cal dir que aquest indret es troba quasi just al límit entre la comarca del Vallès Occidental (on ens trobem ara) i la del Baix Llobregat.

En aquest recorregut, s' han anat tallant en un principi els materials cenozoics (del Miocè Superior) i del Quaternari, els quals reblen la Depressió Prelitoral Catalana, és a dir, els materials que hem vist a la parada anterior. Així, cal dir que hem trobat potents afloraments dels materials quaternaris, especialment de caràcter detrític, tant de derrubis de pendent com d'origen fluvial. Aquests materials presenten unes tonalitats groguenques i rogenques força característiques.

Des d'aquest indret, mirant cap a ponent, es poden veure els interessants xaragalls desenvolupats entre els materials de la bretxa de falla, de la Falla Septentrional del Vallès - Penedès. Això es (FOTOGRAFIA 8) 


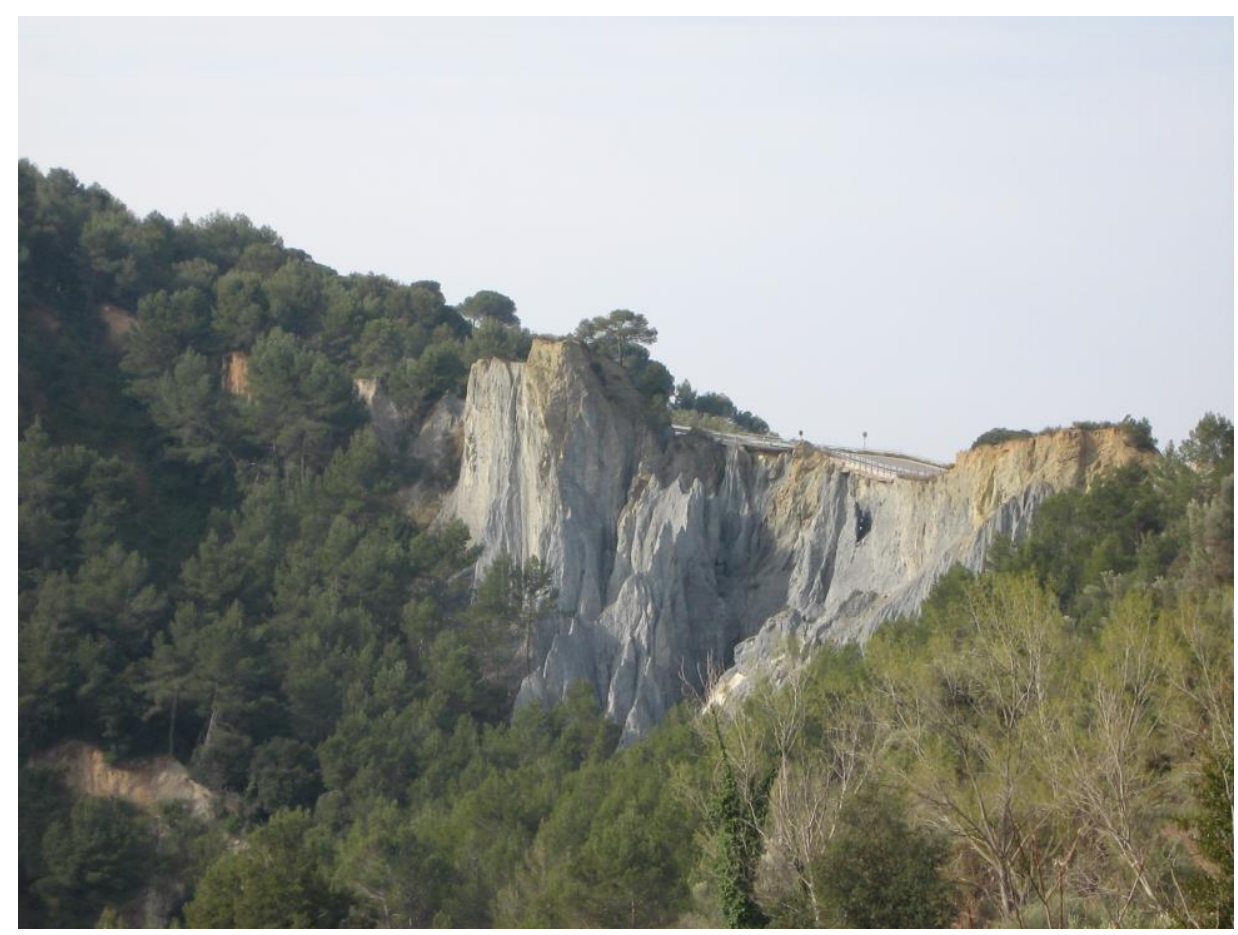

FOTOGRAFIA 8.

Bretxa de falla a Ribes Blaves

\section{PARADA 8. ESTACIÓ DE LA RENFE DE OLESA DE MONTSERRAT, (terme municipal de Viladecavalls del Vallès, comarca del Vallès Occidental). (Full 392).}

Des de la parada anterior cal retornar cap a la cruilla que hem esmentat al recorregut anterior, per la carretera $\mathrm{B}-120$. En arribar a l'esmentada cruilla, ens caldrà seguir cap a Vacarisses per la carretera B - 121. A menys de $1 \mathrm{Km}$ de l'inici de la carretera, es trobarà, també per la dreta, el trencall que ascendeix cap a l'antiga Estació de la RENFE d'Olesa de Montserrat, on es realitzarà la present aturada. Així, des de la parada anterior, haurem recorregut uns $4 \mathrm{Km}$.

En aquest recorregut, $\mathrm{s}$ 'han anat tallant en un principi els materials cenozoics (del Miocè Superior) i del Quaternari, els quals reblen la Depressió Prelitoral Catalana. Tot i així, cap a les immediacions del $\mathrm{Km} 9$ de la carretera que es segueix, (a uns $5 \mathrm{Km}$ de l'inici del recorregut), es comencen a trobar uns nivells de pissarres grisenques, les quals pertanyen a 1'Ordovicià, i es situen dintre de la Serralada Prelitoral Catalana. És a dir, en aquest tram hem sobrepassat la falla que posa en contacte les dues sotsunitats geològiques acabades d'esmentar. Aquests materials paleozoics, constituïts per nivells d'esquistos grisencs, s'aniran trobant i tallant fins a quasi arribar al mateix indret de la present aturada. Tot i així, poc abans d'arribar-hi es comencen a trobar uns nivells de pissarres (llicorelles), que pertanyen probablement al Silurià

En aquest indret, devent mateix de les instal-lacions ferroviàries, es troba el contacte entre els materials paleozoics i els mesozoics. Els primers es troben formats per uns nivells de llicorelles vinoses, que pertanyen probablement al Silurià, les quals es 
troben travessades per freqüents filonets de QUARS. I els segons es troben constituïts per bretxes i per conglomerats quarsosos, així com per gresos, que pertanyen als trams bassals del Buntsandstein (Triàsic Inferior).

El contacte entre els primers i els segons es realitza per duplicat: mitjançant una discordança i una falla quasi vertical que repeteix la primera. Ambdues (la falla i la discordança) estan situades molt properes la una de l'altra. (ESQUEMA 4 i FOTOGRAFIES 9, 10 i 11). La falla abans esmentada provoca l'aixecament del bloc situat a l'esquerra, ja que situa tectònicament els materials del Silurià al mateix nivell que els del Buntsandstein. Igualment es pot observar un apinyament del gruix dels materials del Buntsandstein situats a la dreta de la falla (dreta del dibuix), de forma que cal pensar que a un nivell topogràficament més baixos poden desaparèixer, continuant la falla exclusivament per entre els materials paleozoics del Silurià. També es pot veure el contacte discordant que existeix entre els materials del Buntsandstein i els del Silurià. Aquest contacte és vertical á l'esquerra de la falla, mentre que a la dreta és inclinat

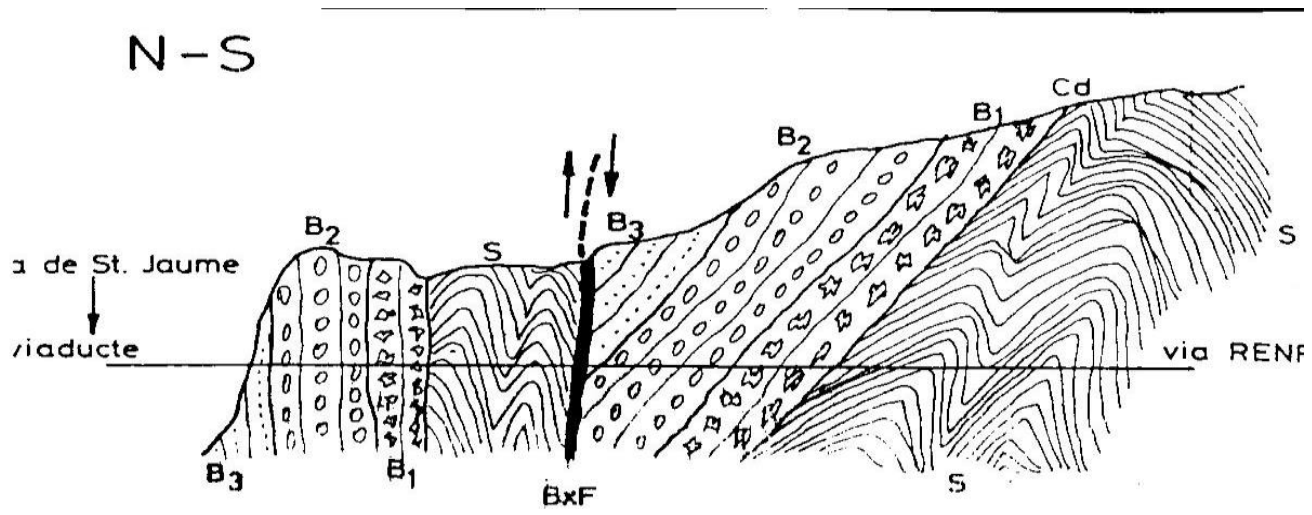

S - Silúric (fil-lites vinoses), B - Buntsandstein, B.1 - Bretxes basals, B.2 - Conglomerats, B.3 - Gresos, $\mathbf{B x F}$ - Bretxa de falla, $\mathbf{C d}$ - Contacte discordant

\section{ESQUEMA 4.}

Tall reproduït de MATA-PERELLÓ (1984a)

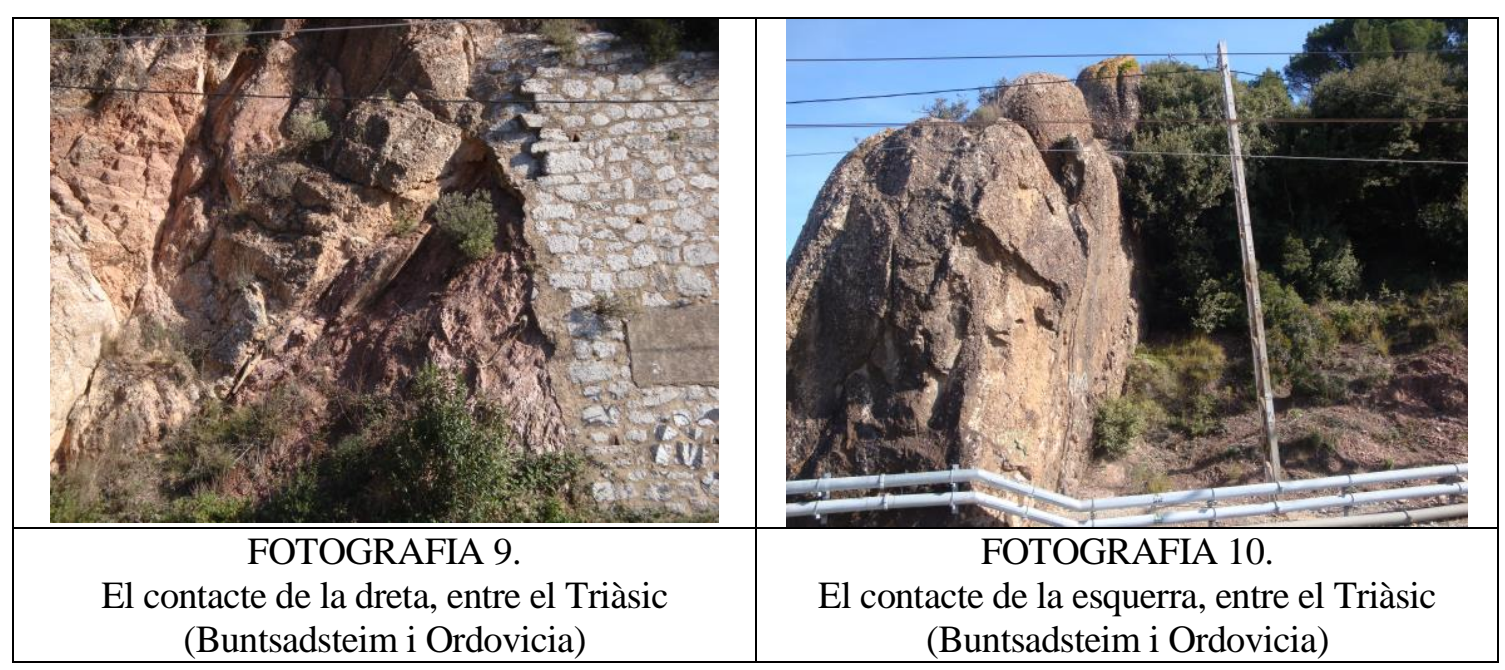




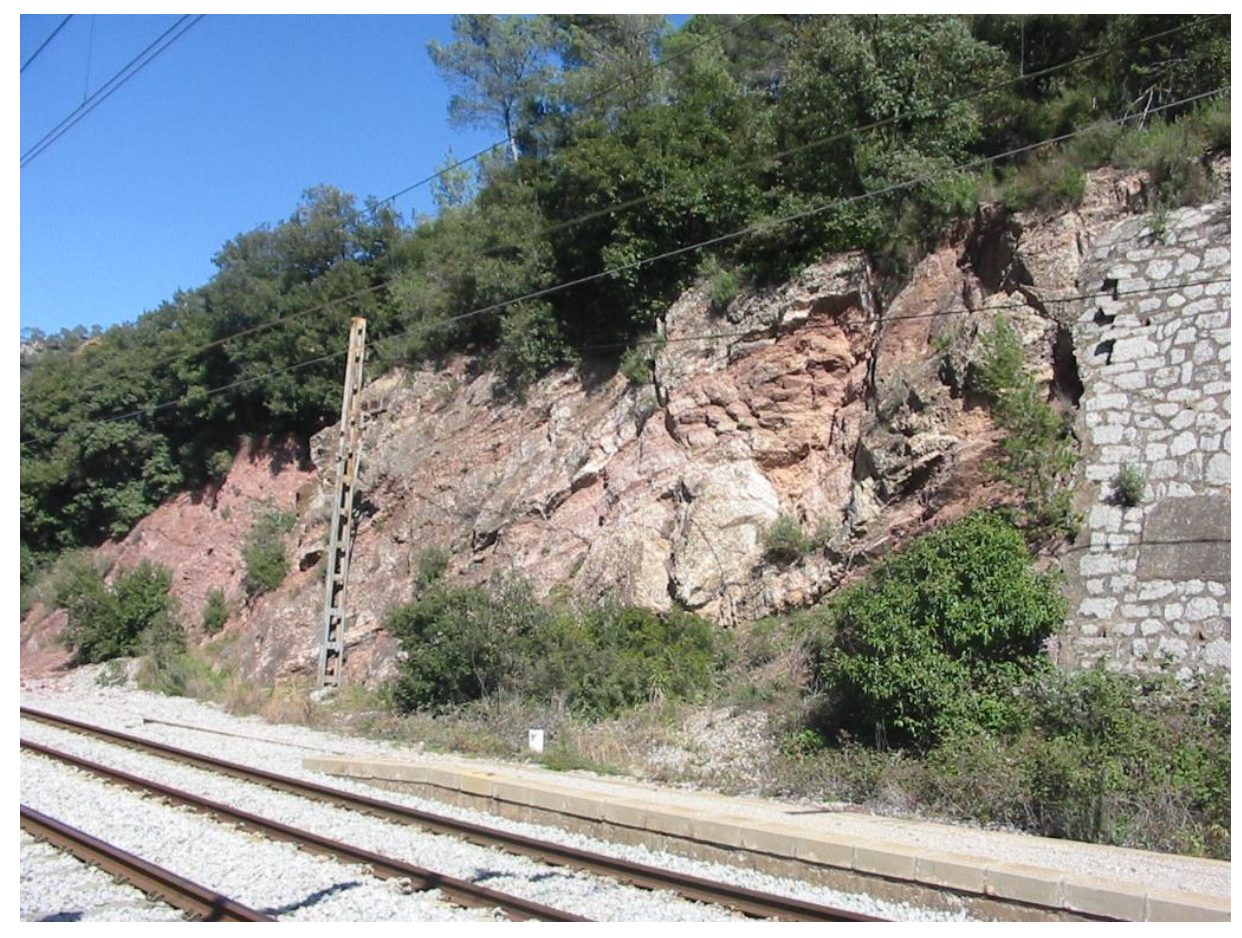

FOTOGRAFIA11.

El contacte de l'Estació de la RENFE d'Olesa de Montserrat

\section{PARADA 9. PEU DEL VIADUCTE SOBRE LA RIERA DE SANT JAUME, (terme municipal d'Olesa de Montserrat, comarca del Baix Llobregat). (Full 392).}

Després de fer la parada anterior, cal baixar per la carretera que neix a l'Estació, la qual es dirigeix a la que enllaça les poblacions d'Olesa de Montserrat i de Vacarisses. En arribar a la cruïlla cal continuar en el sentit de la darrera població. esmentada. Poc després caldrà fer aquesta nova aturada, havent recorregut uns $300 \mathrm{~m}$ des de 1'Estació. En aquesta ocasió ens cal fer l'aturada a la bora de la carretera i caminar uns 100 metres en direcció cap a Vacarisses.

En aquest indret, situat immediatament per sota de l'anterior (sota de l'estació de la RENFE), es pot veure de nou el contacte discordant entre els materials del Buntsandstein i els del Silurià. Aquest contacte, en aquesta ocasió, no es repeteix, i és discordant. Pel que pertoca a la falla visible dalt, a l'estació, continua per entre els materials del Silurià, on s'observa perfectament gràcies a la bretxa de falla. (ESQUEMA 5 i FOTOGRAFIA 12).

És interessant estudiar conjuntament aquest darrer tall amb el vist anteriorment i situat a l'Estació d'Olesa (RENFE), a la PARADA 3. 


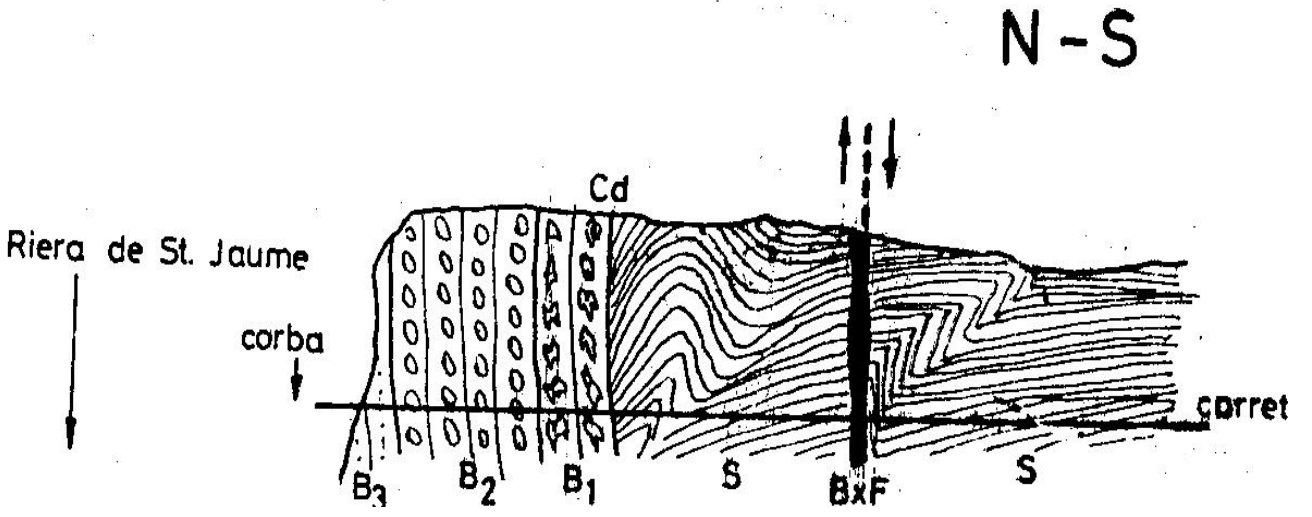

S. Silúric (fil-lites vinoses), B. Buntsandstein, B.1. Bretxes basals, B.2. Conglomerats, B.3. Gresos, BxF - Bretxa de falla, Cd - Contacte discorda

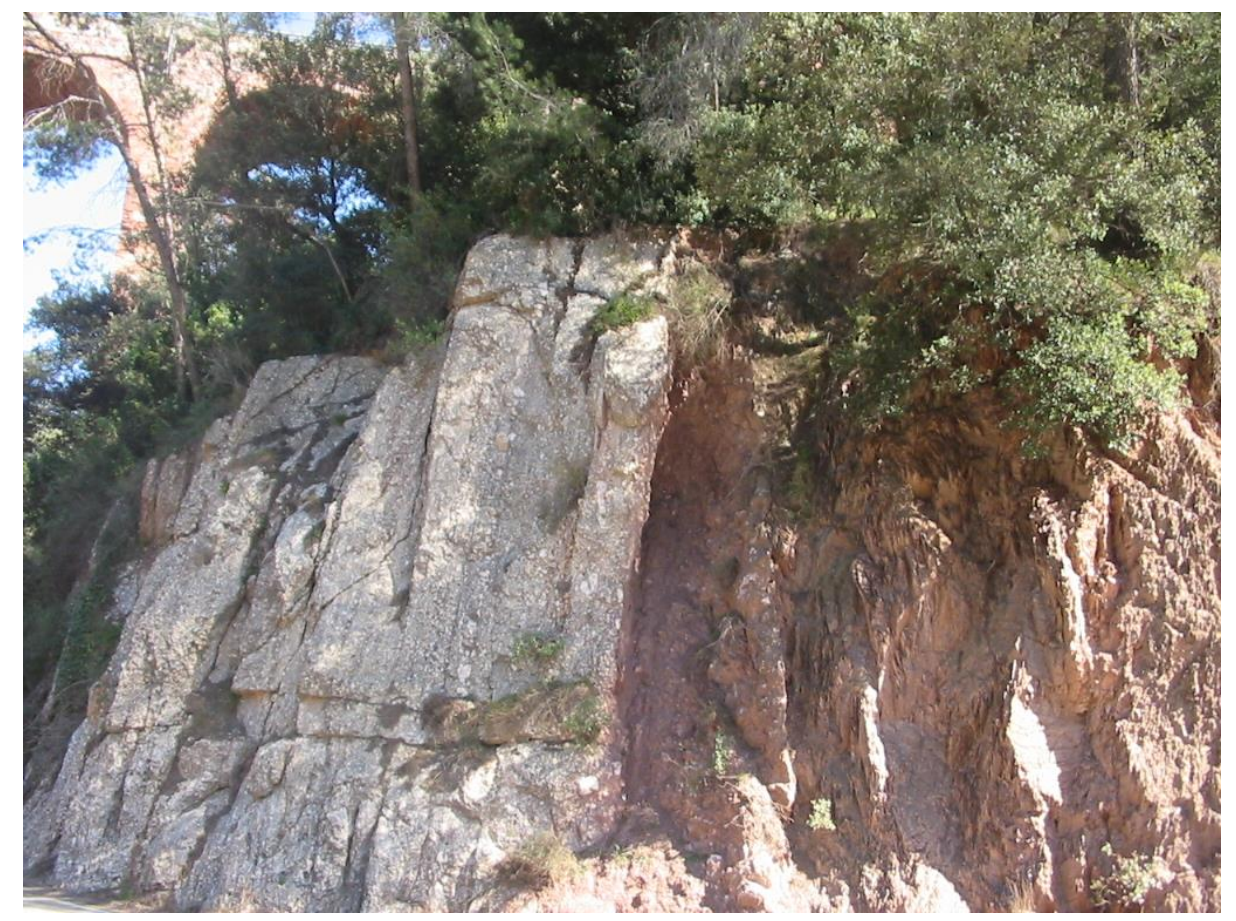

FOTOGRAFIA 12.

Contacte entre el Triàsic i el Paleozoic a la carretera, per sota de 1’Estació de la RENFE d’Olesa de Montserrat

PARADA 10 - CONDICIONAL. IMMEDIACIONS DEL Km 4, (terme municipal de Vacarisses, comarca del Vallès Occidental). (Full 392).

Des de la parada anterior, cal continuar per la carretera que es dirigeix cap a Nord, cap a Vacarisses. En arribar a les immediacions del seu Km 4, farem una nova aturada Pont del Mimó, després de recórrer uns $4 \mathrm{Km}$, des de l'anterior. 
Des de la parada anterior, i fins aquí, s'han anat veient els materials del triàsic. Així, veurem afloraments de les calcàries del Muschelkalk Inferior i els trams vermells del Muschelkalk Mig. Més endavant trobarem afloraments dels materials carbonatats del Muschelkalk Superior.

Finalment, en hem trobat afloraments dels materials cenozoics de la Depressió Geològica de 1'Ebre. Aquests són els materials que apareixen on ara ens trobem. Aquests materials són inicialment del Paleocè-Eocè, $i$ ara ja pràcticament d'aquests darrer període. Aquests nivells es troben constituïts per nivells de gresos i de calcolutites rogenques, amb freqüents filades de conglomerats (així com de bretxes de fragments heteromòrfics $i$ heterogènics).

Des d'aquest indret, mirant cap a l'autopista Terrassa - Manresa, es pot veure com els materials carbonatats del Muschelkak encavalquen als cenozoics que hem acabat d'esmentar.

PARADA 11 - CONDICIONAL. PONT DEL MIMÓ, (terme municipal de Vacarisses, comarca del Vallès Occidental). (Full 392).

Des de la parada anterior, cal continuar per la carretera que es cap al Nord, cap a la propera població de Vacarisses. En arribar al Pont del Mimó, on es farà la present aturada, després de recórrer uns 0’5 Km, des de l'anterior.

Com al recorregut anterior, hem anat trobant afloraments als materials cenozoics del Paleocè - Eocè. En bona part pertanyen a la Formació Cairat i reblen la depressió Geològica de 1'Ebre, en aquest sector de la mateixa.

Des d'aquest indret, i mirant cap a l'ESE, es pot veure l'estructura del Coll Cardús, amb un clar encavalcament, dels materials mesozoics del Triàsic per sobre dels terciaris del Paleocè-Eocè.

\section{PARADA 12. CARRETERA DE L'ABOCADOR DE VACARISSES, (terme de Vacarisses, comarca del Vallès Occidental). (Full 392).}

Des de la parada anterior, cal continuar inicialment cap a Vacarisses, per la carretera que procedeix d'Olesa de Montserrat. Tot i així, en arribar a la cruïlla amb la carretera $\mathrm{C}-58$, cal fer una fillola, agafant-la per tal de dirigir-nos cap a Terrassa. En arribar al Túnel de Coll Cardús, trobarem el trencall que es dirigeix cap a l'Abocador de Vacarisses, ens convindrà fer una breu aturada (d'un 5 minuts i escaig), aturant els vehicles a la porta de l'abocador i caminar uns 100 metres per la carretera C-58. Així, aquí farem una nova aturada, a uns $5 \mathrm{Km}$ de l'anterior.

En aquest recorregut, hem anat trobant afloraments dels materials cenozoics esmentats als recorreguts de les dues aturades anteriors. Aquests són els materials que apareixen a l'indret de l'aturada. Tot i així, en aquest indret, al Nord de la carretera i a uns 100 metres de la mateixa, podem veure com són encavalcats pels terrenys paleozoics de 
l'Ordovicià. Aquesta estructura forma part de l'Encavalcament de les Pedritxes, mitjançant el qual els terrenys paleozoics de la Serralada Prelitoral Catalana es superposen sobre els terrenys terciaris de la Depressió Geològica de l'Ebre. Aquest contacte es pot veure al centre de la FOTOGRAFIA 13.

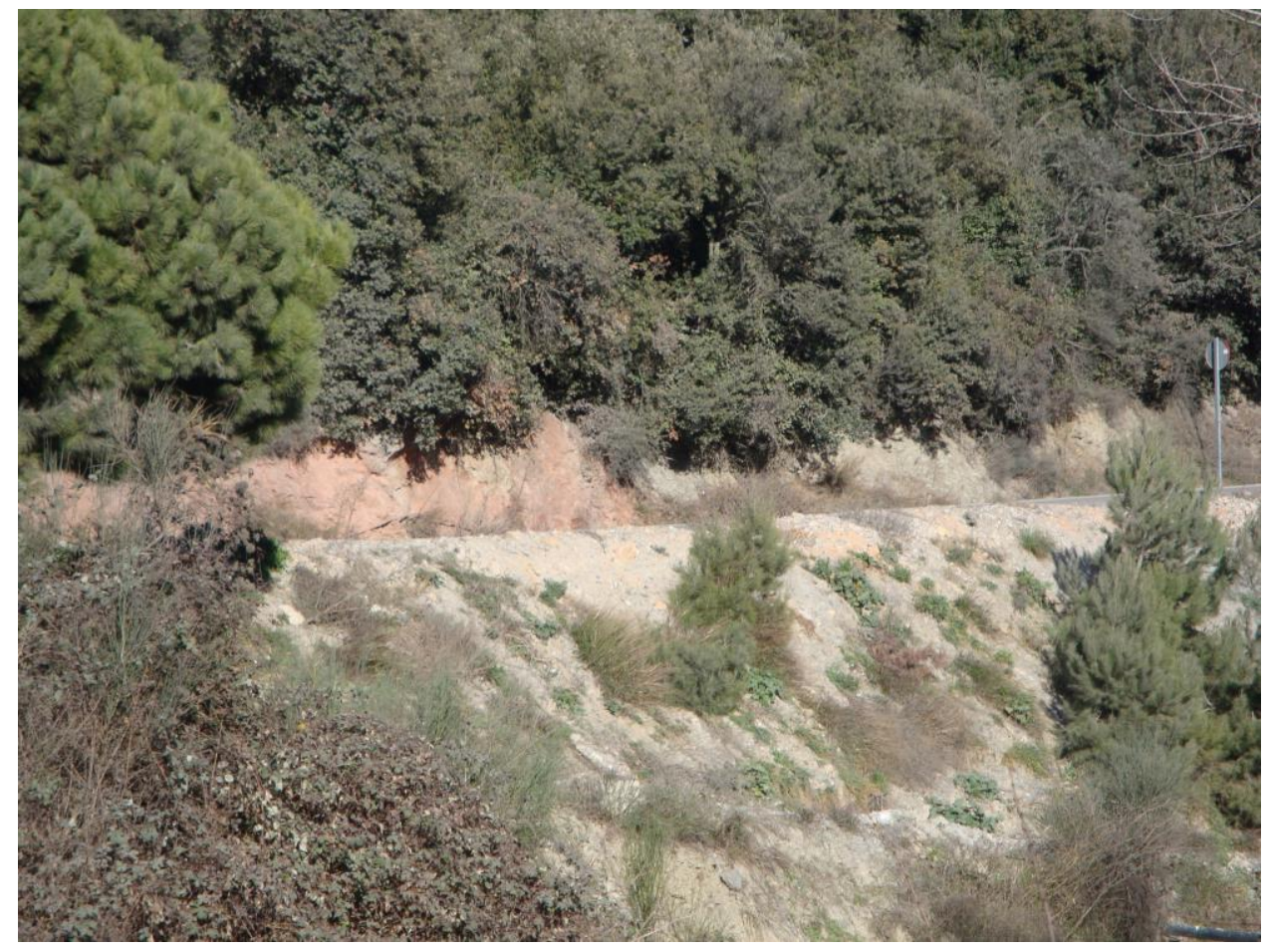

FOTOGRAFIA 13.

Encavalcament del Paleozoic (Ordovicià de la Serralada Prelitoral Catalana) a la dreta, de color gris sobre el Cenozoic (Paleocà - Eocè, de la Depressió Geològica de l'Ebre) a l'esquerra, de tonalitats rogenques. Carretera de 1’Abocador de Vacarisses

\section{PARADA 13. SERRA DE CARDÚS, LA CARENA LLARGA, (terme de Vacarisses, comarca del Vallès Occidental). (Full 392).}

Des de la parada anterior, cal retrocedir fins a la carretera de Vacarisses (la carretera que procedeix d'Olesa de Montserrat) i que passa per sota de la carretera de Terrassa a Manresa. Tot seguit, cal agafar, poc abans de sobrepassar el Km 2 de la carretera, el trencall que se'n per la dreta cap a l'Est, tot dirigint-se cap a la Carena Llarga. Així, caldrà passar per la Font de la Mercè, i per l'Alzina de Boixadell. A uns 3 Km després d'agafar aquest trencall, i després d'haver deixat enrere la urbanització, tot arribant a una cruïlla de tres camins, caldrà fer la present aturada. Així, d'aquesta manera, s'haurà efectuat un recorregut proper als $7 \mathrm{Km}$, des de la parada anterior.

En un principi, s'han continuat tallant els materials del terciari inferior, que pertanyen fonamentalment a l'Eocè. Aquests materials, de la Formació Carme, es troben constituïts per nivells de calcolutites rogenques, les quals es troben alternant amb gresos, també rogencs. Més amunt, prop de l'indret de la parada, els trams es fan cada cop més detrítics. En bona part del recorregut, i mirant cap a Vacarisses, es pot gaudir de 
l'observació dels Cingles de Vacarisses, desenvolupats sobre afloraments de nivells de conglomerats eocènics, i que veurem a la pròxima parada. FOTOGRAFIA 14.

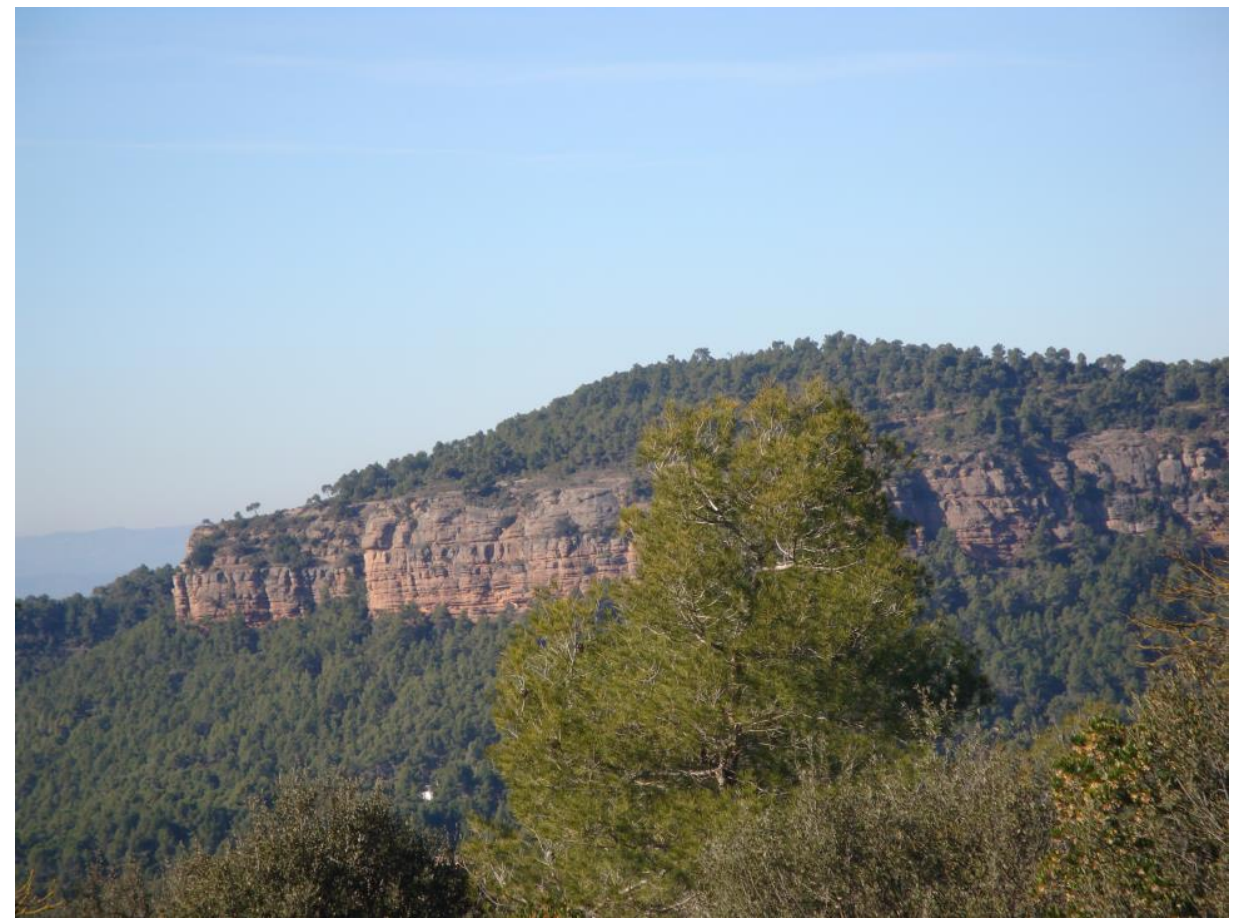

FOTOGRAFIA 14.

Les Cingles de Vacarisses, des de la Carena Llarga.

En aquest indret, es tornen a trobar els nivells pissarrencs del Paleozoic, els quals encavalquen als cenozoics que hem anat trobant fins ara, al llarg de les dues parades anteriors. Aquests materials formen part de l'Encavalcament de les Pedritxes, el qual fa desplaçar uns $4 \mathrm{Km}$ als materials del Paleozoic, per sobre dels del Cenozoic.

Cal fer esment de que entre els afloraments del Paleozoic, que pertanyen probablement a 1'Ordovicià, es troben molts bons exemples de knicks, així com de plecs en chevrón. Per d'altra banda, es troben intensament replegats, i alhora fracturats. Aquest indret, constitueix (en funció de l'encavalcament esmentat, un bon Lloc d'Interès Geològic, un $L I G)$.

\section{PARADA 14. LA BARCELONETA, ELS CINGLES DE VACARISSES, (terme de Vacarisses, comarca del Vallès Occidental). (Full 392).}

Des de la parada anterior, cal retornar a la carretera, per tal de continuar cap a Vacarisses, on conclourà el present itinerari. Així, ens caldrà arribar fins a l'entrada del poble, a la Barceloneta. D'aquesta manera, s'hauran recorregut uns $4 \mathrm{Km}$ més.

En tot el recorregut, s'han continuat trobant els nivells rogencs de 1'Eocè, de la Formació Carme, els quals es troben constituïts per nivells de calcolutites i de gresos, de tonalitats rogenques en ambdós casos. Sovint es troben filades de conglomerats. 
Des d'aquest indret, es pot ben gaudir de la grandiositat dels cingles de Vacarisses, els quals es troben desenvolupats sobre d'uns nivells de conglomerats similars als de la Formació Montserrat. FOTOGRAFIA 15, de la pàgina anterior.

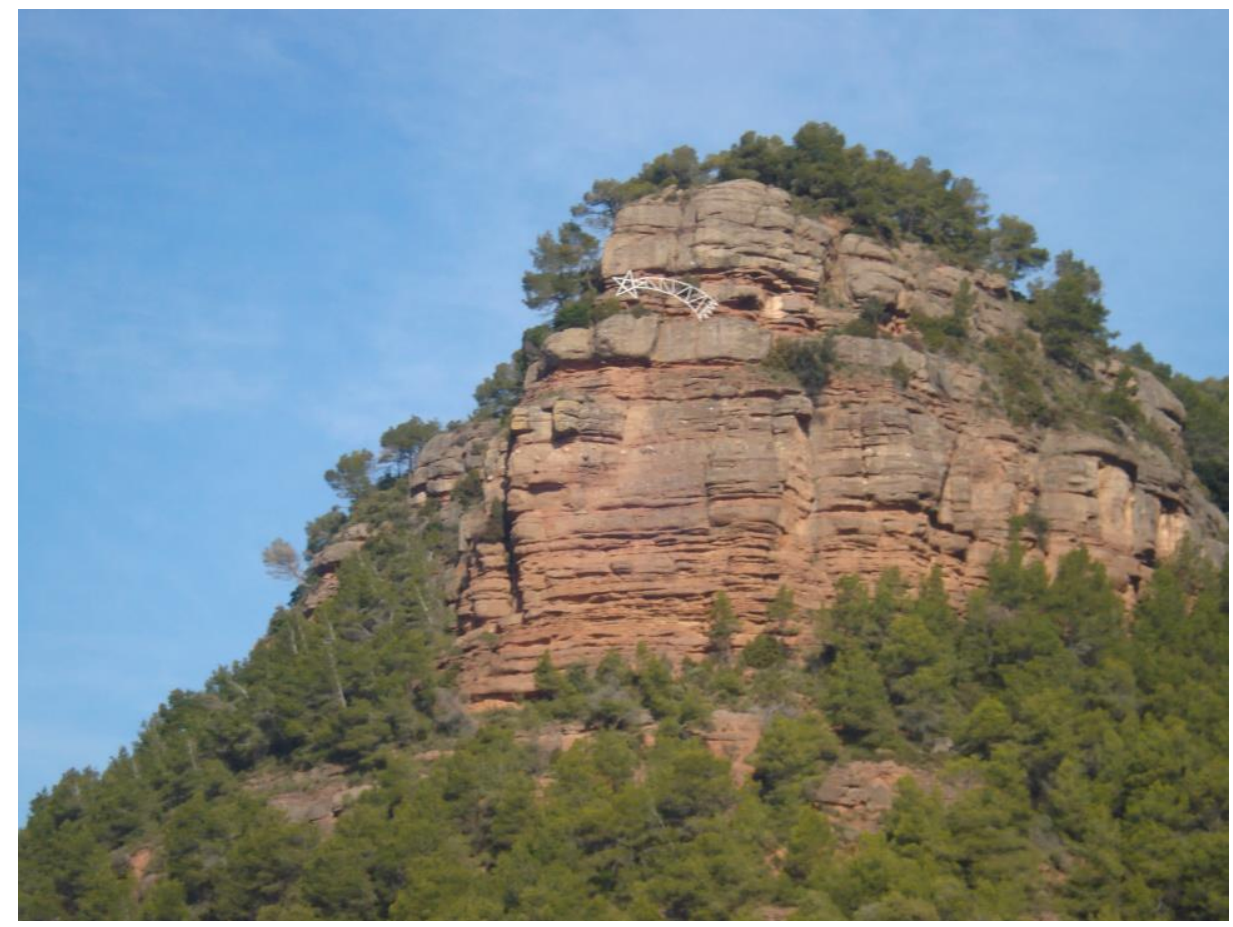

FOTOGRAFIA 15.

Un aspecte dels Cingles de Vacarisses

\section{EN AQUEST INDRET FINALITZA L'ITINERARI}

Tot i això, hi ha la possibilitat de continuar-lo fins a la Bauma (terme de Castellbell i el Vilar), tot seguint la carretera BV-1212 i posteriorment la C - 58. En arribar a aquest indret es podria fer una parada a la sortida del Túnel de la Bauma, amb la finalitat d'observar una sèrie de fractures. Aquestes fractures afecten als materials de 1'Eocè de la Depressió Geològica de l'Ebre.

\section{REFERÈNCIES BIBLIOGRÀFIQUES}

CALZADA, S. i GAETANI, M. (1977).- Nota paleoecológica sobre M. Mentzeli (Brachiopada, Anisiense, Catalánides). Cuadernos de Geología Ibérica, vol 4, Pag. 157-158. Madrid

CALZADA, J. i JAIME, J. de (1978).- Algunos itinerarios geológicos desde Barcelona». Dep. Ciencias Col. San Antonio Abad, Escuelas Pias de San Antonio, Museo Geológico Seminario de Barcelona. Barcelona 
GUIMERÀ, J. et altri (1992).- Geologia (II), Història Natural dels Països Catalans, Vol.2, 547 pag. Enciclopèdia Catalana, S.A. Barcelona.

LLOPIS, N. (1947).- Intrtoducción al estudio de la morfoestructura de los Catalánides. Inst. Lucas Mallada, Consejo Sup. Invest. Científ. 246 pag. Madrid.

MARZO, M. i ANADON, P. (1977).- Evolución y características sedimentológicas de las facies fluviales basales del buntsandsteim de Olesa de Montserrat (Barcelona). Cuadernos de Geología Ibérica, vol. 4, Pg. 211-222. Madrid.

MASACHS, V. et altri (1981).- Itineraris Geològics. Centre d'Estudis Geològics de Manresa-Caixa d'Estalvis de Manresa, 215 pag. Manresa

MATA-PERELLÓ, J.M. (1984a).- Itineraris Geològics per la Serra de Coll Cardús i Viladecavalls (Serralada Prelitoral). Revista Xaragall, nº 7, 34 pag. Manresa.

MATA-PERELLÓ, J.M. (1984b).- Itinerari Geològic per la Riera de Sant Jaume, la Puda i Olesa (Serralada Prelitoral). Revista Xaragall, nº 9, 31 pag. Manresa.

MATA-PERELLÓ, J.M. (1991).- Els Minerals de Catalunya. Arxius de la Secció de Ciències, t. XCIII, 442 pag. Institut d'Estudis Catalans. Barcelona.

MATA-PERELLÓ, J.M. (1995).- Itinerari geològico-mineralògic pel Baix Llobregat: des d'Olesa de Montserrat a l'Aeri de Montserrat. Algeps, sèrie B, $\mathrm{n}^{\mathbf{o}}$ 4, 16 pàgines. Manresa

MATA-PERELLÓ, J.M. (1996).- Itinerari geològic per les comarques del Vallès Occidental i del Baix Llobregat: des de Viladecavalls del Vallès a Sant Pere Sacama i a Olesa de Montserrat. Inèdit, 14 pàgines. Manresa

MATA-PERELLÓ, J.M. (1999).- Itinerari geològic per les comarques del Vallès Occidental i del Baix Llobregat: des de Terrassa i Viladecavalls del Vallès a Olesa de Montserrat. Inèdit.12 pag. Manresa

MATA-PERELLÓ, J.M. (2000).- Itinerari geològic entre la riera de Sant Jaume i la Puda (termes de Viladecavalls del Vallès, Esparreguera i Olesa de Montserrat; Vallès Occidental i Baix Llobregat). Inèdit. 12 pag. Manresa

MATA-PERELLÓ, J.M. (2001).- Itinerari de recerca geològica per les comarques del Baix Llobregat i del Vallès Occidental: recorregut pels termes municipals d'Olesa de Montserrat, de Viladecavalls del Vallès i de Vacarisses. Inèdit. 14 pag. Manresa

MATA-PERELLÓ, J.M. (2005).- Recorregut de recerca geològica i mineralògica per les comarques del Baix Llobregat i Anoia: des Collbató i el Bruc a Òdena. Inèdit. 12 pag. Manresa 
MATA-PERELLÓ, J.M. (2006).- Itinerari de recerca geològica per les comarques del Baix Llobregat i del Vallès Occidental: des d'Olesa de Montserrat a Torreblanca. Inèdit. 14 pag. Manresa

MATA-PERELLÓ, J.M. (2007).- Itinerari geològic per les comarques del Vallès Occidental, Baix Llobregat i Anoia: des de Viladecavalls del Vallès a Olesa de Montserrat, Esparreguera, Collbató i al Bruc. Inèdit. 26 pag. Manresa

MATA-PERELLÓ, J.M. (2009a).- Itinerari geològic per les comarques del Baix Llobregat i del Vallès Occidental: des d'Olesa de Montserrat a Ribes Blaves, a Sant Pere Sacama i a Sant salvador de les Espasses. Inèdit. 16 pàgines. Manresa

MATA-PERELLÓ, J.M. (2009b).- Itinerari geològic per la comarca del Vallès Occidental: des de Viladecavalls del Vallès a 1'Estació d'Olesa de Montserrat i a Vacarisses. . Inèdit. 12 pàgines. Manresa

MATA-PERELLÓ, J.M. i CLIMENT I COSTA, F. (2010).- Coneix ... la Geologia des del Baix Llobregat. Edicions del Llobregat. Centre d'Estudis de la Comarca del Baix Llobregat. 51 pàgines. Sant Feliu de Llobregat.

MATA-PERELLÓ, J.M. i MONTANÉ GARCÍA, P. (2005).- Sortida de recorregut geològic pel sud del Bages i pel Baix Llobregat Nord: des de Monistrol de Montserrat a Esparreguera a Olesa de Montserrat i al Cairat. Inèdit. 12 pag. Manresa

RIBA, O. et altri (1976).- Geografia Física dels Països Catalans, 205 pag. Edit. Ketres. Barcelona

SOLER, A. (1982).- La tectònica alpina a la Serralada Pre-litoral Catalana en el sector comprès entre el Balneari de la Puda de Montserrat, Serra de Coll Cardús i la Serra d'en Font. Acta del Grup Autònom de Manresa, de la Inst. Catalana d'Hist. Natural, Manresa

VIRGILI, C. (1958).- El Triásico de los Catalánides. Bol. Inst. Geol. Minero de España, t.45, 368 pag. Madrid 